Pacific Journal of Mathematics

A NOTE ON EXTREMAL LENGTH AND MODULUS 


\section{A NOTE ON EXTREMAL LENGTH AND MODULUS}

\section{RICHARD KATZ}

\section{The equality of extremal length and modulus is shown for general annuli in a Riemannian manifold.}

In a recent paper, [2], Ow showed that the modulus and extremal length of an annulus in a Riemannian manifold are equal under the assumption that the set of critical points of the harmonic measure of the annulus has capacity zero. The purpose of this note is to show that this condition can be dispensed with. We refer the reader to [2] for definitions.

Theorem. The extremal length $(\lambda)$ and modulus $(\mu)$ of an annulus $(\Omega, \alpha, \beta)$ are equal.

Proof. The inequality $\lambda \geqq \mu$ was shown in [2].

To show the opposite inequality, let $u$ be the harmonic measure of $(\Omega, \alpha, \beta)$, and $h$ be a function such that

$$
h|\alpha=0, h| \beta=1,\left|\nabla h^{2}-\nabla u^{2}\right|<\varepsilon,
$$

and $h$ has only a finite number of critical points in $\Omega$. For the existence of such a function see Milnor [1]. Let $\Gamma_{0}$ be the set of integral curves of $\nabla h$ which do not meet a critical point and $P$ the set of admissible densities on $\Omega$. It is immediate that $|\Gamma h| \in P$. Now for $\gamma \in \Gamma_{0}, \rho \in P$

$$
\int_{\Omega} \rho^{2} d V=\int_{\alpha}\left(\int_{Y} \frac{\rho^{2}}{\nabla h^{2}} d h\right) * d h \geqq \int_{\alpha}\left(\int_{\gamma}\left|\frac{\rho}{\nabla h}\right| d h\right)^{2} * d h
$$

and

$$
\int_{\alpha}\left(\int_{\gamma}\left|\frac{\rho}{\nabla h}\right| d h\right)^{2} * d h=\int_{\alpha}\left(\int_{i} \rho d l\right)^{2} * d h \geqq \inf _{\Gamma_{0}}\left(\int_{i} \rho d l\right)^{2} \int_{\alpha} * d h
$$

Since $\left|\nabla h^{2}-\nabla u^{2}\right|<\varepsilon$, it follows that

$$
\left|\int_{\alpha} * d h-\mu^{-1}\right|<\varepsilon V(\Omega)
$$

and therefore,

$$
\lambda \leqq \sup _{P} \inf _{\Gamma_{0}} \frac{\left(\int_{Y} \rho d l\right)^{2}}{\int_{\Omega} \rho^{2} d V} \leqq \mu+K \varepsilon
$$


for a suitable constant $K$. Since $\varepsilon$ was arbitrary, we have $\lambda \leqq \mu$ which completes the proof.

\section{REFERENCES}

1. J. Milnor, Lectures on the h-cobordism theorem, Princeton University Press, Princeton, N. J., 1965.

2. W. Ow, An extremal length criterion for the parabolicity of Riemannian spaces, Pacific J. Math. 23 (1967), 585-590.

Received March 4, 1968.

California State College

Los Angeles, California 


\section{PACIFIC JOURNAL OF MATHEMATICS}

\section{EDITORS}

H. ROYDEN

Stanford University

Stanford, California

\section{R. $R$ PHELPS}

University of Washington

Seattle, Washington 98105

\section{J. DugunduI}

Department of Mathematics

University of Southern California

Los Angeles, California 90007

RICHARD ARENS

University of California

Los Angeles, California 90024

\section{ASSOCIATE EDITORS}

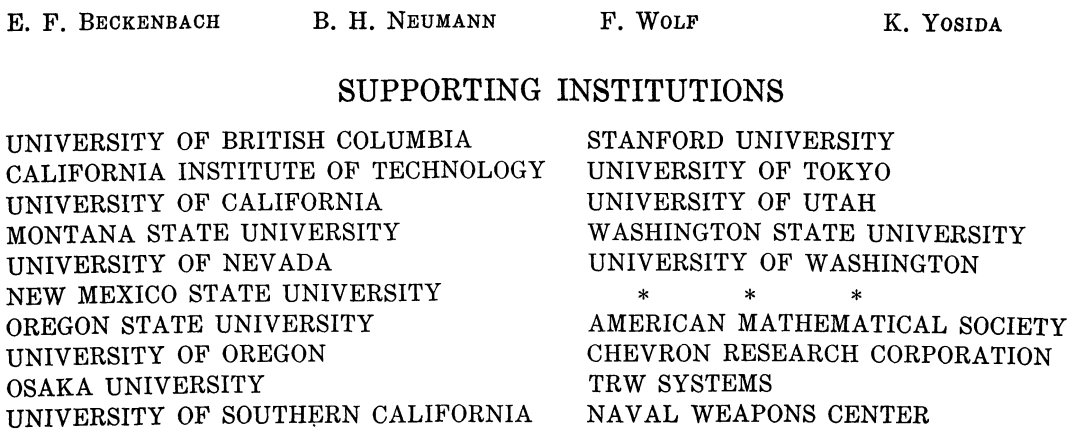

The Supporting Institutions listed above contribute to the cost of publication of this Journal, but they are not owners or publishers and have no responsibility for its content or policies.

Mathematical papers intended for publication in the Pacific Journal of Mathematics should be in typed form or offset-reproduced, double spaced with large margins. Underline Greek letters in red, German in green, and script in blue. The first paragraph or two must be capable of being used separately as a synopsis of the entire paper. It should not contain references to the bibliography. Manuscripts, in duplicate if possible, may be sent to any one of the four editors. Please classify according to the scheme of Math. Rev. 36, 1539-1546. All other communications to the editors should be addressed to the managing editor, Richard Arens, University of California, Los Angeles, California, 90024.

50 reprints are provided free for each article; additional copies may be obtained at cost in multiples of 50 .

The Pacific Journal of Mathematics is published monthly. Effective with Volume 16 the price per volume (3 numbers) is $\$ 8.00$; single issues, $\$ 3.00$. Special price for current issues to individual faculty members of supporting institutions and to individual members of the American Mathematical Society: $\$ 4.00$ per volume; single issues $\$ 1.50$. Back numbers are available.

Subscriptions, orders for back numbers, and changes of address should be sent to Pacific Journal of Mathematics, 103 Highland Boulevard, Berkeley, California, 94708.

PUBLISHED BY PACIFIC JOURNAL OF MATHEMATICS, A NON-PROFIT CORPORATION

Printed at Kokusai Bunken Insatsusha (International Academic Printing Co., Ltd.), 7-17, Fujimi 2-chome, Chiyoda-ku, Tokyo, Japan. 


\section{Pacific Journal of Mathematics}

Vol. 28, No. $2 \quad$ April, 1969

Richard Arens and Donald George Babbitt, The geometry of relativistic

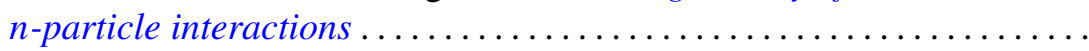

Kirby Alan Baker, Hypotopological spaces and their embeddings in lattices

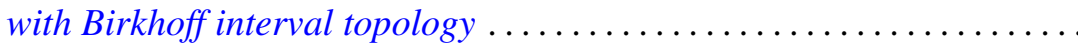

J. Lennart (John) Berggren, Finite groups in which every element is conjugate to its inverse ........................... 289

Beverly L. Brechner, Homeomorphism groups of dendrons . . . . . . . . . . . 295

Robert Ray Colby and Edgar Andrews Rutter, QF - 3 rings with zero singular ideal ................................. 303

Stephen Daniel Comer, Classes without the amalgamation property....... 309

Stephen D. Fisher, Bounded approximation by rational functions ......... 319

Robert Gaines, Continuous dependence for two-point boundary value problems..................................... 327

Bernard Russel Gelbaum, Banach algebra bundles ............... 337

Moses Glasner and Richard Emanuel Katz, Function-theoretic degeneracy criteria for Riemannian manifolds ...................... 351

Fletcher Gross, Fixed-point-free operator groups of order $8 \ldots \ldots \ldots \ldots 357$

Sav Roman Harasymiv, On approximation by dilations of distributions . . . . 363

Cheong Seng Hoo, Nilpotency class of a map and Stasheff's criterion ... . . 375

Richard Emanuel Katz, A note on extremal length and modutus.......... 381

H. L. Krall and I. M. Sheffer, Difference equations for some orthogonal polynomials ................................

Yu-Lee Lee, On the construction of lower radical properties ........... 393

Robert Phillips, Liouville's theorem........................... 397

Yum-Tong Siu, Analytic sheaf cohomology groups of dimension $n$ of

n-dimensional noncompact complex manifolds ..... . .

Michael Samuel Skaff, Vector valued Orlicz spaces. II...

James DeWitt Stein, Homomorphisms of $B^{*}$-algebras .... . .

Mark Lawrence Teply, Torsionfree injective modules .... . . .

Richard R. Tucker, The $\delta^{2}$-process and related topics. II .

David William Walkup and Roger Jean-Baptiste Robert Wets, Lifting

projections of convex polyhedra...

Thomas Paul Whaley, Large sublattices of a lattice. 